Article

\title{
Is the Commercialization of Wild Plants by Organic Producers in Austria Neglected or Irrelevant?
}

\author{
Christoph Schunko * and Christian R. Vog1 1 \\ Department of Sustainable Agricultural Systems, University of Natural Resources and Life Sciences \\ Vienna (BOKU), Gregor-Mendel-Strasse 33, 1180 Wien, Austria; christian.vogl@boku.ac.at \\ * Correspondence: christoph.schunko@boku.ac.at; Tel.: +43-47654-93348
}

Received: 15 October 2018; Accepted: 30 October 2018; Published: 31 October 2018

check for updates

\begin{abstract}
European countries are split over the appreciation of wild berries, fruits, mushrooms, and herbs. While some countries provide public statistics on wild plants, others seem to neglect wild plant gathering and commercialization. In this study, we aimed to understand if wild plant commercialization is neglected or irrelevant in Austria, a country that does not provide statistics. We focus on organic producers, because organic certification of wild plant gathering might have potential for countering frequent concerns about commercial gathering, including destructive gathering and overharvesting. Using a mixed-methods approach with a concurrent triangulation design, databases of six organic certification bodies were analysed concurrently with semi-structured expert interviews of their representatives. We found that organic certification for gathering was issued to $1.5 \%$ of organic producers in the year 2016 in Austria and is relevant for three distinct gatherer types: regular, diversified, and single-plant gatherers. Organic gathering is most frequently part of agricultural or horticultural farms and rarely an isolated commercial activity. It is related to mixed farming, deepening on-farm diversification, and contributes to maintaining traditions, as well as the local socio-ecological memory of wild plant products. Organic wild plants are directly marketed to consumers as traditional and innovative products, but also supplied to mass markets. We conclude that from a socio-cultural perspective and a focus on regional economies, organic gathering is neglected in Austria, whereas from an income perspective, wild plant gathering seems to be indeed relevant for few organic producers, although exhibiting potential.
\end{abstract}

Keywords: foraging; health food; traditional knowledge; neglected and underutilized species; non-timber forest product; organic farming; superfood; wild edible plant; wild food

\section{Introduction}

Several European countries provide public statistics about the gathering and commercialization of wild plants, including wild berries, fruits, mushrooms, and herbs, and recognize their socio-cultural and economic importance, while others seem to neglect wild plant gathering and commercialization [1]. In addition to uneven data availability, European countries focus on distinct aspects of wild plant gathering and lack harmonization of their data collection, which hampers comparability $[1,2]$. The accuracy of Europe-wide statistics is thus poor, whereas provisional calculations suggest that the market value of wild plants sums up to at least 1.66 billion Euros [2].

Although reliable statistics are largely unavailable, several value chains for wild plant commercialization in Europe are identified. Entering the market through complex international, straightforward local, or intermediary value chains, wild plants are commercialized in mass markets, specialized niche markets, and as emblematic regional products in local markets [3]. Mass markets were found to be relevant for single species in Northern, Eastern, and Southern European countries, for example, blueberries in Latvia and Finland [4,5]; porcini in Finland [6]; saffron milk cap in 
Spain [7]; chestnuts in Italy and Switzerland [3]; several herbs, including sage, thyme, and lavender, in Albania [8]; and several berry, mushroom, and herb species in Serbia [9].

In specialized niche markets, a much larger diversity of species and products are offered [9-12]. For example, at four open-air markets in Poland, 60 wild plant and mushroom species were commercialized [11]; and in shops and markets in Thessaloniki, Greece, 99 wild medicinal plant species were commercialized [10]. While at mass markets mainly traditional wild plant products are commercialized, at niche markets, wild plants are processed into innovative products [3], as, for example, country wines, which are non-grape wines made from wild leaves, berries, or flowers, made by a Scottish company $[3,13]$.

As emblematic regional products, wild plants support the sale of a range of regional products and services [3], such as tourism and recreation, handcrafts, education and nature conservation, foods, and cosmetics [14]. For example, in the south-east Austrian Zirbenland (Land of Stone Pines), a range of wild plant products are made with the wood, needles, and cones of the stone pine and marketed in conjunction with tourist activities [15].

Frequent concerns associated with commercial wild plant gathering are destructive gathering techniques, overharvesting, or exploitation of the workforce [16]. Certifying wild plant species can counter these concerns and enhance ecologically sustainable and socially responsible production standards [17]. Organic certification of internationally traded wild plants was, for example, shown to provide socio-economic benefits for gatherers and better management practices in forests [18]. Certification schemes relevant for wild plant gathering include standards focusing on forest management (for example Forest Stewardship Council [19]), organic production and processing (for example IFOAM [20]), and social standards (for example Fairtrade [21]), or a combination of these (for example Fairwild [22]). Another concern relates to the presence of toxic elements in gathered wild plants and mushrooms, caused by, for example, ubiquitous pollution or local natural influences like the geology of the collection site $[23,24]$. Such concerns are usually covered by food safety authorities and are not addressed by organic certification. Organic certification-being the most common certification scheme for wild plants in Europe-is regulated by European Council Regulations No. 834/2007 [25] and No. 889/2008 [26]. These regulations determine that wild plants and mushrooms can be certified as organic (i) when the gathering areas have not been treated with products forbidden in organic agriculture for three consecutive years; (ii) when the gathering does not impair the stability of the habitat and maintenance of the species in the gathering area [25]; and (iii) when the gathering follows a series of control arrangements for organic production [26].

Similar to the unequal data availability for wild plant gathering in Europe, understanding about the relevance of organic gathering is also unequally distributed and most often poorly developed. While organic certified wild gathering areas were reported for 23 European countries [27], countries with a large demand for organic products (Germany, France) and Eastern European countries with potentially high volumes gathered (Poland, Hungary) did not provide information about organic gathering. Among the countries reporting organic gathering areas, Finland has the largest area worldwide (12.2 million hectares). The European countries ranking next are Romania (1.8 million hectares), Bulgaria (0.9 million hectares), Macedonia (0.6 million hectares), and Albania and Ukraine (0.5 million hectares each) [27]. Although the size of gathering areas is reported, no information about the diversity or volumes of wild plant species gathered is given. Therefore, these statistics again provide only incipient understanding about the relevance of organic gathering.

Being stimulated by this lack of understanding, in this study, we aimed to understand if organic gathering is carelessly-because it has more relevance than the absence of data would let us assume-neglected or irrelevant in one country which does not provide statistics on wild plant gathering, organic or not: Austria. We therefore adopted a broad view on relevance, including quantitative and qualitative parameters in a mixed-methods research approach. On the quantitative side, we understood relevance as the diversity and volumes of wild plants commercialized by organic producers, whereas on the qualitative side, we aimed for understanding the relevance of organic 
gathering for different producer types. We understood organic producers as farmers and other businesses that were certified for organic production and organic gatherers as organic producers who were certified for wild plant commercialization. Organic wild plants were considered as those being certified by certification bodies as such. This included wild mushrooms, which are interpreted as wild plants in the application of EC organic regulation. We thus adopted our definition of wild plants from the organic certification bodies and did not assess ourselves if the plant species certified as wild were indeed not domesticated and not grown under any human selection pressure that might lead to domestication.

\section{Materials and Methods}

\subsection{Study Area}

The study was conducted in Austria (Europe), a country with a population of 8.8 million inhabitants [28] and a size of $84,000 \mathrm{~km}^{2}$. Recent studies found that organic producers, non-organic producers, and rural dwellers gather and use wild plants for food, medicine, veterinary medicine, and customs in several parts of Austria [29-32]. Austria was found to be an exception to the general rule that German speaking countries tend to be mycophobic [33]. The population is allowed to access forests and gather wild plants for household use-whereas mushroom gathering is restricted to a volume of up to two kg per day-unless explicitly prohibited. For commercial gathering of fruits and seeds of many trees and shrubs, permission has to be obtained from the forest owner (\$174 Austrian Forest Act). Although these findings may anticipate some relevance of wild plant commercialization, prior studies did not perceive wild plant gathering as commercially important in comparison with other non-timber forest products, such as hunting, tourism, recreation, education, and nature conservation [14,34]. Wild plant products seem to provide additional income rather than being main economic pillars for producers [34] and are mainly relevant in local trade [15]. Precise accounts are, however, absent, including those on organic gathering [27].

Animal farming of cattle, sheep, and goats ( $36 \%$ of all farms) and forestry ( $30 \%$ of all farms) characterize agriculture in Austria, while crop cultivation (13\% of all farms) is less pronounced [35]. Having $21.9 \%$ of the utilized agricultural area under organic certification and about $19 \%$ of all farms certified as organic, Austrian farmers are forerunners in organic agriculture [35]. This abundance of organic farming makes Austria an especially interesting case for studying organic gathering.

In addition, the geography of Austria seems to provide particularly suitable conditions for gathering a diversity of wild plant species. The landscape is characterized by a mosaic of small patches of land cover and Austria is among the countries with the highest landscape diversity in Europe [36]. The prevailing land cover is woodland with, compared to other Central European countries, a high percentage of $47 \%$ of total land cover; $24 \%$ of the area is covered with grassland and $18 \%$ with cropland [37]. The Austrian flora contains about 3300 vascular plant species in 740 genera and 152 plant families [38].

\subsection{Mixed Methods Research Approach}

This study is based on a mixed-methods approach using the concurrent triangulation design [39], which means that a quantitative approach (analysis of data received from organic certification bodies) and a qualitative approach (semi-structured expert interviews) were followed concurrently in the data collection and analysis, and merged only in the interpretation and discussion phases. Giving both research approaches equal weight, two different samples, two data collection strategies, and two procedures for data analysis were followed concurrently.

The methods' design relied on organic certification bodies, which are in charge of controlling and certifying the conformity of organic production processes and labelling with organic regulations. In Austria, six certification bodies are accredited for controlling and certifying organic producers 
(Table 1). Only one organic certification body (LVA) focusing on organic processors was not involved in this study.

The second author contacted the heads of the certification bodies via email to introduce the content and purpose of the study and to ask for support. In cases where the heads were not able to support the study themselves, a representative could be nominated. Positive replies were obtained from all six certification bodies and in three cases, the heads of the certification bodies, and in three cases, nominated representatives, were the contact points. All six have long-time work relations with their certification body and extensive experience in controlling and certifying organic producers. They are thus conceptualized as experts, understood as persons who have accumulated specific knowledge about a clearly defined problem area and are in the position to shape and structure the problem area for others [40].

Table 1. Certification bodies controlling and certifying organic producers in Austria.

\begin{tabular}{|c|c|c|c|c|}
\hline Certification Body & Certification Code & $\begin{array}{c}\text { Number of Organic } \\
\text { Producers Certified in } 2016\end{array}$ & $\begin{array}{l}\text { Year of First Organic } \\
\text { Certification }\end{array}$ & Address, Website \\
\hline $\begin{array}{l}\text { ABG-Austria } \\
\text { Bio Garantie }\end{array}$ & AT-BIO-301 & 10,700 & 1993 & $\begin{array}{c}\text { Königsbrunnerstraße 8, } \\
2202 \text { Enzersfeld } \\
\text { www.abg.at }\end{array}$ \\
\hline $\begin{array}{c}\text { BIOS-Biokontrollservice } \\
\text { Österreich }\end{array}$ & AT-BIO-401 & 1850 & 1994 & $\begin{array}{l}\text { Feyregg } 39,4552 \text { Wartberg } \\
\text { www.bios-kontrolle.at }\end{array}$ \\
\hline $\begin{array}{c}\text { Lacon } \\
\text { GmbH-Prüfinstitut } \\
\text { Certification code }\end{array}$ & AT-BIO-402 & 4000 & 1999 & $\begin{array}{c}\text { Am Teich 2, } 4150 \text { Rohrbach } \\
\text { www.lacon-institut.at }\end{array}$ \\
\hline $\begin{array}{l}\text { SLK-Salzburger } \\
\text { Landwirtschaftliche } \\
\text { Kontrolle GmbH } \\
\text { Certification code }\end{array}$ & AT-BIO-501 & 3800 & 1995 & $\begin{array}{c}\text { Kleßheimer Straße 8a, } 5071 \text { Wals } \\
\text { www.slk.at }\end{array}$ \\
\hline $\begin{array}{l}\text { Kontrollservice } \\
\text { BIKO Tirol }\end{array}$ & AT-BIO-701 & 2200 & 1994 & $\begin{array}{c}\text { Wilhelm-Greil-Straße 9, } \\
6020 \text { Innsbruck } \\
\text { www.biko.at }\end{array}$ \\
\hline $\begin{array}{c}\text { SGS-Austria } \\
\text { Controll-Co. GmbH }\end{array}$ & AT-BIO-902 & 1400 & 2000 & $\begin{array}{l}\text { Grünberggasse } 15,1120 \text { Wien } \\
\text { https:// www.sgs-kontrolle.at/ } \\
\text { bio/biolandwirtschaft.htm }\end{array}$ \\
\hline
\end{tabular}

\subsection{Data Collection}

The experts were asked to support the project in two ways. First, they were asked to make and share a query of their internal databases. The parameters of interest included:

(1) registration numbers of producers certified for organic gathering;

(2) certified wild plant and mushroom species per producer;

(3) volumes gathered per plant and mushroom species.

All experts agreed to make the query for the year 2016 and delivered the data in Microsoft Excel files [41].

Second, the experts were asked for their consent and availability for semi-structured expert interviews [40]. All again agreed and the first author of the paper travelled to the offices of the six certification bodies for personal interviews. The interview guideline included questions on how the EU organic legislation was implemented regarding wild plant gathering, the related challenges for certification bodies, supporting and limiting factors for wild plant commercialization (both not presented here), and the characteristics of producers requesting organic wild plant certification and the relevance for these producers.

All interviews took place in a one-to-one setting between the experts and the first author. The semi-structured interviews were conducted between 15th February and 28th March 2017 in German language and were recorded with a digital voice recorder. The entire interviews lasted between 40 and $80 \mathrm{~min}$. 


\subsection{Data Analysis}

The data received from the organic certification bodies was aggregated into one single spreadsheet in Microsoft Excel, listing in the columns the certification body, registration number of producer, gathered plant item, and volume gathered per plant item. We decided to refer to plant items (see Table S1), since the data received included several degrees of detail about plant species and plant parts gathered. Indications for plant species included names on generic, genus, and species levels in local dialects, in German as well as in botanical names. The plant parts gathered were partly indicated, partly not. To allow a common analysis, plant species were lifted to the genus level unless generic names were given from which plant genera could not be inferred. For the translations between local and German names to botanical names, the Flora of Austria [38] and the Medicinal Plant Name Services [42] were used.

The registration numbers of producers were used to make queries about the producers in the Integrated Administration and Control System (IACS), a database for managing and controlling direct payments to producers [43] and administered by the Austrian Federal Ministry of Agriculture, Forestry, Environment and Water Management. Thus, all producers applying for direct payments are listed in this database. Through these queries, we received data about 21,822 organic producers in Austria, including size of land (in hectares), kind of producer (forestry, field crops, horticulture, permanent crops, grazing livestock, granivores, mixed [44]), and state where the producer is located. Among all 352 organic producers certified for wild plant gathering in Austria, 283 were listed in the IACS. The reason for non-inclusion is that producers work on very little or no land and are thus not eligible for receiving payments.

The data received from organic certification bodies and through IACS were first analysed with descriptive statistics. Pearson Correlation (variables: organic gathering (yes/no) and size of land) and $\mathrm{Chi}^{2}$-tests (variables: organic gathering and kind of producer; organic gathering and location of producer) were then used to identify patterns for wild plant gathering. The significance level of $p=0.05$ was applied for identifying significant relations and standardized residuals were interpreted as indicating deviations from the expected frequency at a value below -2 or above 2 . For the $\mathrm{Chi}^{2}$-tests, variables have been modified to receive no cells with expected counts less than five; therefore, horticultural producers (19 organic producers all over Austria) and the State of Vienna (40 organic producers) had to be excluded from the analysis. All calculations were completed in SPSS24 [45].

The semi-structured expert interviews were transcribed for detailed analysis and deductive coding. Sub-codes were added while coding. Memos were written as patterns came up during and after coding. All coding and memo writing was performed in Atlas.ti7 [46]. The expert perceptions were-justified by the conceptualization of interviewees as experts-treated as representative and reliable in the analysis [40].

A typology of organic wild plant producers was created through clustering text into groups based on selected criteria and in a way that within group similarity is high (internal homogeneity), whereas between group similarity is low (external heterogeneity). Typologies sharpen the view on similarities and dissimilarities and thus the diversity of cases [47]. The typology was created in four steps: definition of criteria and coding (codes i-iv), transfer and grouping of codes in a Microsoft Excel matrix, review of groups to achieve consistent types, and characterization of types [47].

\subsection{Limitations of the Study}

There are both strengths and weaknesses to relying on data from third parties. Our study benefits from data received from organic certification bodies to provide a first-time overview of the wild plant diversity gathered in Austria. However, the level of detail of the data received was insufficient for analysis at a species-level and we thus had to lift the data to a genus-level. In addition, information on plant parts gathered or products made were insufficient and data about the volumes gathered were only available for about half of the organic gatherers. Although the producers are obliged to document the volumes gathered per plant species, the organic inspector may check this documentation on site 
directly and does not have to insert this data into the internal database. Since the data analysed in this study were received from queries of certification bodies' internal databases, these data remain incomplete. The volume gathered was available for 163 producers. Although this represents only about half of the producers, the volumes are representative across the genera (variables: number of plant items per genus and number of plant items per genus with volume given; CorrelationSpearman: $\mathrm{r}=0.826 ; p<0.001$ ). Although we thus benefitted from the data received, we were confronted with several limitations.

Additionally, we studied the commercialization of organic wild plants sourced in Austria and did not consider the commercialization of imported organic wild plant products or of non-organic wild plant products. The results are thus limited to activities of organic producers and we therefore do not provide information about the availability of organic and non-organic wild plant products on the Austrian market in general.

We also adopted our definition of wild plants from the organic certification bodies and did not evaluate if the wild plant species certified were actually wild or domesticated. The distinction between wild and domesticated plant species can be worthwhile to study more closely in organic farming, because, in our assessment, a harmonized clear distinction is not yet made. Cases that may be difficult to assess might, for example, include domesticated plants growing in abandoned agricultural plots or wild plants that are cultivated in agricultural plots and gathered, or even harvested with combine harvesters, there.

Organic control bodies accumulate a multitude of experiences in everyday exchange with producers. Being in unique positions for informing about developments in the organic sector, representatives of organic control bodies were selected as respondents. Whereas the close work relationships between inspectors and producers might bear potential to influence results, we do not believe that our results were systematically altered. The work of the control bodies consists of objectively verifying the conformity of production processes and product labelling against organic production standards. Control bodies thus have a rather neutral position towards individual producers and there is neither the need nor opportunity to adopt a position.

The sample size of six respondents is lower than many other qualitative studies. However, research has shown that small sample sizes can identify overarching themes in experiences and perceptions of a rather homogeneous sample [48]. We argue that our research approach fulfils these preconditions and our experiences in analysing the data also hint to data saturation for the high level of analysis chosen.

\section{Results}

\subsection{Plant Diversity and Volumes}

In the year 2016, organic certification for gathering wild plants was issued by Austrian organic certification bodies to $352(1.5 \%)$ out of about 24,000 Austrian organic producers. Altogether, 2316 plant items were certified, including 495 different ones. This includes 63 items (19 different ones) on a generic level or in local dialects, which could not be related to a plant genus. The remaining 2253 plant items were assigned to 242 different plant genera. The ten plant genera containing the largest numbers of plant items are Sambucus (178 plant items), Rubus (162), Urtica (96), Vaccinium (82), Achillea (81), Allium (76), Taraxacum (75), Tilia (68), Plantago (62), and Rosa (58). The fungi genera with the largest numbers of items are Boletus (6) and Cantharellus (5).

Organic gatherers are certified for a median of three plant items, $1 \mathrm{~km}$ per plant item, and a total volume of $15 \mathrm{~kg}$. The $75 \%$ quartiles are at seven plant items, $3 \mathrm{~kg}$ per plant item, and $45 \mathrm{~kg}$ or total volume per organic gatherer (Table 2).

Among all 163 organic gatherers reporting volumes, four gathered more than one ton of one plant item. These are two producers gathering Allium ursinum, one producer gathering branches of 
Pinus mugo, and a fourth gathering new shoots of Picea abies. Allium ursinum is commercialized as food, whereas Pinus mugo and Picea abies are used in cosmetics.

Table 2. Plant diversity and volumes commercialized by organic producers in Austria.

\begin{tabular}{ccccccc}
\hline Category & \multicolumn{5}{c}{ Percentile } & $n$ \\
\hline & $5 \%$ & $25 \%$ & $50 \%$ & $75 \%$ & $95 \%$ & \\
Plant items gathered/producer (count) & 1 & 1 & 3 & 7 & 21 & 352 \\
Volume gathered/producer (in kg) & 1.5 & 5.4 & 15 & 45 & 406 & 163 \\
Volume gathered/plant item (in kg) & 0.1 & 0.3 & 1 & 3 & 35 & 163 \\
Volume gathered/plant genus (in kg) & 0.1 & 0.4 & 2.5 & 21 & 326 & 163 \\
\hline
\end{tabular}

\subsection{Producer Characteristics}

Among all 21,822 organic producers in Austria included in the IACS and thus receiving direct payments, $283(1.3 \%)$ received organic certification for wild plant gathering. Conversely, 69 organic gatherers did not receive direct payments. Since data about a producer's characteristics are only available for producers receiving direct payments, further calculations are based on these 283 producers.

The mean size of land of organic gatherers is 21 hectares (standard deviation 20.4). Most producers are specialised in grazing livestock (136 producers), forestry (42), field crops (42), and mixed farming (38), and are located in Upper Austria (75 producers), Lower Austria (66), and Styria (63).

The size of land of producers has no influence on organic gathering (Pearson Correlation: $r=0.01, p=0.155)$, whereas the kind of producer and location of producer significantly relate to organic gathering ( $\mathrm{Chi}^{2}$-test: $p \leq 0.001$ for both): among mixed farmers, significantly more producers are certified for organic gathering than expected (standardized residuals: 5.2); and in the state of Upper Austria, more producers are certified for organic wild plant gathering than expected (standardized residuals: 3.0), and in Tyrol, Salzburg, and Burgenland, each exhibits less (standardized residuals: $-3.9,-2.7$, and -2.1 , respectively) (Table 3).

Table 3. Crosstabs showing kind and location of producer contrasted with organic gathering $\left(\mathrm{Chi}^{2}{ }^{2}\right.$-test: $p=<0.001$ for both tests; $n=21,822$ ).

\begin{tabular}{|c|c|c|c|c|c|}
\hline & & Statistics & $\begin{array}{c}\text { Organic Producers } \\
\text { with Wild } \\
\text { Plant Certification }\end{array}$ & $\begin{array}{l}\text { Organic Producers } \\
\text { without Wild } \\
\text { Plant Certification }\end{array}$ & Total \\
\hline \multirow{8}{*}{$\begin{array}{l}\text { Kind of } \\
\text { producer }\end{array}$} & \multirow{2}{*}{ Forestry } & Count & 42 & 3393 & 3435 \\
\hline & & Standardized Residual & -0.3 & 0.0 & \\
\hline & Field crops & Count & 42 & 3084 & 3126 \\
\hline & $\begin{array}{c}\text { Permanent } \\
\text { crops }\end{array}$ & Standardized Residual & 2.0 & -0.2 & \\
\hline & \multirow{2}{*}{$\begin{array}{l}\text { Grazing } \\
\text { livestock }\end{array}$} & Count & 136 & 12,468 & 12,604 \\
\hline & & Standardized Residual & -2.0 & 0.2 & \\
\hline & Granivores & Count & 3 & 418 & 421 \\
\hline & Mixed & Standardized Residual & 5.3 & -0.6 & \\
\hline \multicolumn{2}{|c|}{ Total } & Count & 280 & 21,521 & 21,801 \\
\hline
\end{tabular}


Table 3. Cont.

\begin{tabular}{|c|c|c|c|c|c|}
\hline & & Statistics & $\begin{array}{c}\text { Organic Producers } \\
\text { with Wild } \\
\text { Plant Certification }\end{array}$ & $\begin{array}{l}\text { Organic Producers } \\
\text { without Wild } \\
\text { Plant Certification }\end{array}$ & Total \\
\hline \multirow{12}{*}{$\begin{array}{c}\text { Location of } \\
\text { producer }\end{array}$} & \multirow{2}{*}{ Burgenland } & Count & 5 & 959 & 964 \\
\hline & & Standardized Residual & -2.1 & 0.2 & \\
\hline & Carinthia & Count & 29 & 1575 & 1604 \\
\hline & Lower Austria & Standardized Residual & 0.2 & 0.0 & \\
\hline & \multirow{2}{*}{ Upper Austria } & Count & 75 & 4007 & 4082 \\
\hline & & Standardized Residual & 3.0 & -0.3 & \\
\hline & Salzburg & Count & 28 & 3528 & 3556 \\
\hline & Styria & Standardized Residual & 1.8 & -0.2 & \\
\hline & \multirow{2}{*}{ Tyrol } & Count & 8 & 2227 & 2235 \\
\hline & & Standardized Residual & -3.9 & 0.4 & \\
\hline & \multirow{2}{*}{ Vorarlberg } & Count & 8 & 472 & 480 \\
\hline & & Standardized Residual & 0.7 & -0.1 & \\
\hline \multicolumn{2}{|c|}{ Total } & Count & 282 & 21,500 & 21,782 \\
\hline
\end{tabular}

\subsection{Gatherer Types}

We identified three distinct gatherer types among organic producers for whom wild plant gathering is of relevance: the regular, the diversified, and the single-plant gatherers (Table 4).

The regular gatherer is by far the most common one. Being already equipped with direct marketing structures and processing facilities for their main businesses, mostly agricultural and horticultural farms, these gatherers use wild plant products to complement their existing product ranges. They gather and process the wild plant parts by themselves and use the direct marketing structures available for their commercialization. These producers can be smaller or larger, but they gather a few plant species only and the volumes gathered are typically small. The wild plants are gathered in proximity to the producers and frequently on their own or neighbouring lands. The products made include traditional products of a region, such as herbal teas, jams, syrups, schnapps, and liqueurs, but especially young farming families also use wild plants for experiments and innovations of traditional products. Although this gatherer type includes a variety of different kinds of producers, their cohesive traits are the availability of marketing structures and processing facilities that are then also used for wild plant processing and sale. A typical statement for this gatherer type is: 'that's basically the classic direct marketers; these include a wide range of producers from small to big, producers having three products including one Schnapps made of Stone pines or huge direct marketers with wide product ranges' (IP3, literal translation).

The diversified gatherers are less common. These gatherers also process the wild plants on their production sites and market directly to consumers. In contrast to the regular gatherers, they specialize to some extent in wild plants and gather large diversities of species, whereas the volumes gathered per species can vary. They also innovate traditional products or produce innovative products, such as health foods. Diversified gatherers typically participate in formal courses on wild plant gathering and use (for example herbal pedagogy) and engage in self-learning to deepen their knowledge. They are exceptionally interested in wild plants and may be worried by the loss of traditional knowledge. A typical statement for this gatherer type is: 'on the other side we have many many new age wild plant gatherers, an esoteric generation who starts to revive old things through gathering wild plants to large extents' (IP1, literal translation). 
The single-plant gatherers are very scarce. They gather single species in large volumes and sell the unprocessed plant parts to processors or retailers. These gatherers are thus also specialized in wild plant gathering, but they specialize in gathering large volumes rather than large diversities. Bear leek (Allium ursinum) and Alpine valerian (Valeriana celtica) are plant species that are typically gathered by this gatherer type. Gathering activities are limited to the areas where the intended plant species grow in large extents. A typical statement for this gatherer type is: 'we do have one very special matter, in Carinthia they gather Alpine valerian for a producer in Germany which makes soaps, this is a very special form of gathering' (IP3, literal translation).

Table 4. Typology of organic gatherers based on perceptions of experts of organic control bodies $(n=6)$.

\begin{tabular}{|c|c|c|c|}
\hline Type & Single-Plant Gatherers & Diversified Gatherers & Regular Gatherers \\
\hline Number of producers & small & small & large \\
\hline Species diversity gathered/producer & very small & large & small to medium \\
\hline Volume gathered/species & large & small to medium & small \\
\hline Producer characteristics & $\mathrm{n} / \mathrm{a}$ & $\mathrm{n} / \mathrm{a}$ & $\begin{array}{l}\text { smaller and larger; across all } \\
\text { federal states, production and } \\
\text { landscape types }\end{array}$ \\
\hline Role in product range & central & central & peripheral \\
\hline Processing of plants & not processed & processed & processed \\
\hline Characteristic products & $\begin{array}{l}\text { Allium ursinum, } \\
\text { Valeriana celtica }\end{array}$ & $\begin{array}{l}\text { innovative products (for } \\
\text { example health foods) }\end{array}$ & $\begin{array}{l}\text { traditional products and } \\
\text { innovations thereof: herbal tea, } \\
\text { jam, syrup, schnapps, liqueur }\end{array}$ \\
\hline Way of commercialization & to processors or retailers & to consumers & to consumers \\
\hline Principal knowledge sources & $\mathrm{n} / \mathrm{a}$ & $\begin{array}{c}\text { formal courses on wild plant } \\
\text { uses (for example herbal } \\
\text { pedagogy) and self-learning }\end{array}$ & traditional and local knowledge \\
\hline Gathering areas & $\begin{array}{l}\text { well-chosen specific } \\
\text { areas where plant species } \\
\text { occur in abundance }\end{array}$ & $\mathrm{n} / \mathrm{a}$ & $\begin{array}{l}\text { self-owned or neighbouring areas, } \\
\text { occasionally in further distances }\end{array}$ \\
\hline
\end{tabular}

\section{Discussion}

\subsection{Plant Diversity and Volumes Commercialized}

This study shows that a significant diversity of wild plant items, attributable to 242 (33\%) of the 740 plant genera in Austria, is gathered and certified as organic products in Austria. The diversity of wild plant species commercialized is rarely taken into account in research, but wild plant species are typically clustered in generic categories, such as fruits, berries, mushrooms, or medicinal (for example [9,27], or just single plant species are monitored. However, research at four open-air markets in Poland, where 60 wild plant and mushroom species were commercialized [11], or in shops and markets in Thessaloniki, Greece, where 99 wild medicinal plants were commercialized [10], indicated that a large number of wild plant species are commercialized across Europe.

Two plant genera are especially popular and each gathered by about half of the organic gatherers: Sambucus and Rubus. Sambucus is the elderberry genera and especially the flowers, leafs, and fruits of the black elderberry (Sambucus nigra) are used in Austria as food and medicine. The flowers are used in tea, syrups, or fermented as wine; the leafs are used in tea; and the fruits are processed to make juices, jams, and wine [31,49]. Rubus contains a long list of distinct species of blackberries and raspberries. The fruits are mainly used raw or processed to make jams, and the leaves are mixed into tea. Although these two plant genera were frequently mentioned as useful in ethnobotanical studies about subsistence gathering in rural areas in Austria in previous studies [31,49], the frequent use and especially the gap to subsequent plant genera are still astonishing, indicating cultural relevance.

Additionally, the infrequent commercialization of mushrooms is remarkable. While for organic producers in one region in south-east Austria mushrooms are among the most popular wild plant species gathered for household use [31], our study finds that the commercialization of organic wild mushrooms sourced in Austria is rare. This is in contrast with findings from non-certified gathering 
in other parts of Europe, where mushrooms are very popular and value chains range from local to international [3,6,7], and the fact that Austrians tend to be mycophilic [33]. Potential explanations could include the low compatibility of mushroom gathering with the organic certification processes. Mushrooms are a dispersed forest resource and gatherers used to walk for several hours through several forest patches for picking. These forest patches usually have different owners and gatherers would need-from each forest owner separately-approval for gathering and confirmation of conformity with organic regulations, which may be an administrative burden that is too high.

Although the diversity of wild plant species commercialized is quite outstanding, the volumes commercialized by most organic gatherers seem comparably modest. For example, while professional pickers of wild edible mushrooms in Finland gathered about $370 \mathrm{~kg}$ per person in the year 2008, organic gatherers in Austria gathered a median of $15 \mathrm{~kg}$ of wild plants in the year 2016. This, however, could also be a misleading impression since several $\mathrm{kg}$ of flowers or leafs can already be a significant volume with economic relevance. Moreover, several organic gatherers do indeed gather larger diversities ( $25 \%$ of organic gatherers at least seven plant items, $5 \%$ at least 21 plant items) or larger volumes ( $25 \%$ of organic gatherers at least $45 \mathrm{~kg}$, $5 \%$ at least $406 \mathrm{~kg}$ ), which indicates at least some economic relevance for the most active organic gatherers. However, without knowing the plant parts gathered, we could not go into more detail in calculating the economic value. This thus still needs to be achieved in a future study to draw a more detailed picture.

\subsection{Producer Characteristics}

The size of land of producers has been shown to be unrelated to organic gathering in our study. This result may, however, be biased because of incomplete data availability. While in Austria, about $91 \%$ of all organic producers receive direct payments and are included in the Integrated Administration and Control System (IACS) [43], only about $80 \%$ of all organic gatherers are included in IACS. Since the main reason for non-inclusion is a small size of land, this means that a small size of land is overrepresented in our total sample of 352 producers, but not reflected in the results, since calculations could only be made with the 283 producers for which land size was available in the IACS.

The kind of producers most likely to be certified for organic gathering are mixed farms. Mixed farms are especially known for on-farm diversification activities [50]; above all a deepening form of diversification where added value is generated through extending production activities to on-farm processing and sale [51]. Organic gathering fits well into this diversification pattern since most wild plant items are processed before sale and sold directly to consumers.

We also identified the geographic variability of organic gathering in Austria. The states of Tyrol and Salzburg, where significantly less producers are certified for organic gathering, are situated in mountain areas in Western Austria where livestock farming and forestry prevail and where farming is increasingly a part-time rather than professional endeavour. Farming families tend to reduce original farming activities and either engage in agritourism or accept off-farm employment instead [52], which yields higher returns. These structures do not favour deepening farm diversification and organic gathering, but a broadening diversification, based on agritourism [51].

Other factors supporting farm diversification include the availability of a family workforce, young age of farm households, or seasonality of farming type with less work in parts of the year [51]. These factors may also be related to organic gathering and should be tested in future studies.

\subsection{Producer Types}

We identified three typical ways of how organic producers incorporate wild plant gathering into their businesses. The most common way is to include organic gathering as a peripheral activity of agricultural or horticultural farms to complement existing product ranges. On-farm diversification activities and already existing processing facilities and infrastructure for direct sale support the commercialization, whereas size of land seems to be unrelated. This gatherer type makes up the core of organic gatherers in Austria and all plant genera gathered frequently, above all Sambucus and 
Rubus, owe this frequency to the activities of this type. The direct economic relevance is eventually minor, but the sale of wild plant products on a regional level can have other relevance. This includes wild plants that are commercialized as emblematic regional products that enhance the trademark of a region, which markets other products and services, for example, for tourism [3]. Regional wild plant commercialization can also support traditional land uses [15], contribute to maintaining traditions [53] and reinforcing cultural identity [54], and support communication and memory about wild plant products and manufacturing at household levels. Regional wild plant commercialization may thus play a role in maintaining and adapting local ecological knowledge and the socio-ecological memory in a region [55]. The socio-cultural and indirect economic relevance may thus outweigh the direct economic relevance for this type of gatherer.

The second typical, but much less widespread, way is that organic producers rely on wild plant gathering and processing as a central activity of their farms or other businesses. Gathering large diversities and comparably larger volumes, these producers essentially contribute to the large diversity of organic wild plants gathered in Austria. These producers tend to commercialize wild plants as health foods and innovative products. They are in line with the trend for acknowledging the health benefits and functional traits of wild plant products [56,57], which is also appreciated by consumers [58]. The trend for innovative wild food products on the consumption side thus manifests in a distinct gatherer type on the production side.

The third typical way is similar to the prior one in giving a central role to wild plants and in being rare, although dissimilar, in gathering even larger volumes, but single plant species only. This type gathers for mass markets, which was suggested to be hardly competitive in Austria because of high production costs [34]. Although our study is in line with this earlier result in principle, single plant species are still gathered in large volumes and enter mass markets as foods (Allium ursinum) and ingredients for cosmetics (Pinus mugo, Picea abies, Valeriana celtica). In other European countries, the large-scale gathering of single wild plant species was reported more extensively. For example, national and international value chains developed around gathering, transporting, processing, and trading wild herbs in Albania [8], saffron milk caps in Spain [59], porcini in Finland [6], and blueberries in Latvia [4], with thousands of rural dwellers benefitting from commercial gathering through earning significant incomes. Such elaborated value chains were not identified in Austria. However, in future studies, it would be worthwhile to investigate the factors supporting large-scale gathering and commercialization to understand the necessary conditions.

\section{Conclusions}

Setting out to determine the relevance of organic gathering by organic producers in Austria, we applied a concurrent mixed-methods approach [39]. We find that the results of the quantitative and qualitative methods converge and that organic gathering has socio-cultural and economic relevance in Austria because:

(1) a large diversity of wild plants are gathered and commercialized;

(2) wild plant products support mixed agricultural and horticultural farmers and deepening on-farm diversification through being complementary products for their product ranges;

(3) direct marketing of wild plants supports the maintenance of traditional products and the local socio-ecological memory of wild plant products;

(4) wild plant products support the trend for health foods and are a source for innovative products;

(5) single wild plant species are valuable for mass markets.

Is the commercialization of wild plants by organic producers in Austria neglected? We conclude from our study that the answer depends on the perspective. From a socio-cultural perspective and a focus on regional economies, wild plant gathering is neglected, and the points of relevance listed above are ignored by public authorities. However, from an income perspective, wild plant gathering seems 
to be indeed relevant for few organic producers in Austria. This lack of direct economic relevance may again be linked to the lack of political attention given to wild plant gathering in Austria.

We claim that the recognition of the socio-cultural and economic relevance of wild plant gathering by public authorities would sharpen and broaden the view on wild plant commercialization, open up further business opportunities, and support monitoring of the sustainability of gathering activities. The collection of at least basic data on a national level about the producers commercializing wild plants and on the species commercialized would be a valuable first step towards this recognition.

Supplementary Materials: The following are available online at http:/ / www.mdpi.com/2071-1050/10/11/3989/ s1, Table S1: Organic wild plant items as recorded by organic certification bodies and frequency of certification.

Author Contributions: Conceptualization, C.S. and C.R.V.; Methodology, C.S. and C.R.V.; Writing-original draft, C.S.; Writing—review \& editing, C.S. and C.R.V.

Funding: This research received no external funding.

Acknowledgments: The authors are grateful to the organic certification bodies controlling and certifying organic producers in Austria-ABG, BIKO, BIOS, LACON, SGS, SLK - for providing database information on organic gathering and sharing experiences. Moreover, we are thankful to Otto Hofer who, on behalf of the Austrian Federal Ministry of Agriculture, Forestry, Environment and Water Management, supported the study through making socio-demographic data about organic producers available.

Conflicts of Interest: The authors declare no conflict of interest.

\section{References}

1. Turtiainen, M.; Nuutinen, T. Evaluation of information on wild berry and mushroom markets in European countries. Small-Scale For. 2012, 11, 131-145. [CrossRef]

2. State of Europe's Forests 2015; Forest Europe Liaison Unit Madrid: Madrid, Spain, 2015.

3. Pettenella, D.; Secco, L.; Maso, D. NWFP\&S Marketing: Lessons Learned and New Development Paths from Case Studies in Some European Countries. Small-Scale For. 2007, 6, 373-390. [CrossRef]

4. Grivins, M. A comparative study of the legal and grey wild product supply chains. J. Rural Stud. 2016, 45, 66-75. [CrossRef]

5. Vaara, M.; Saastamoinen, O.; Turtiainen, M. Changes in wild berry picking in Finland between 1997 and 2011. Scand. J. For. Res. 2013, 28, 586-595. [CrossRef]

6. Cai, M.; Pettenella, D.; Vidale, E. Income generation from wild mushrooms in marginal rural areas. For. Policy Econ. 2011, 13, 221-226. [CrossRef]

7. Voces, R.; Diaz-Balteiro, L.; Alfranca, Ó. Demand for wild edible mushrooms. The case of Lactarius deliciosus in Barcelona (Spain). J. For. Econ. 2012, 18, 47-60. [CrossRef]

8. Imami, D.; Ibraliu, A.; Gruda, N.; Skreli, E.; Fasllia, N. Analysis of the Medicinal and Aromatic Plants Value Chain in Albania. Gesunde Pflanzen 2015, 67, 155-164. [CrossRef]

9. Keča, L.; Keča, N.; Rekola, M. Value Chains of Serbian Non-Wood Forest Products. Int. For. Rev. 2013, 15, 315-335. [CrossRef]

10. Hanlidou, E.; Karousou, R.; Kleftoyanni, V.; Kokkini, S. The herbal market of Thessaloniki (N Greece) and its relation to the ethnobotanical tradition. J. Ethnopharmacol. 2004, 91, 281-299. [CrossRef] [PubMed]

11. Kasper-Pakosz, R.; Pietras, M.; Łuczaj, Ł. Wild and native plants and mushrooms sold in the open-air markets of south-eastern Poland. J. Ethnobiol. Ethnomed. 2016, 12, 45. [CrossRef] [PubMed]

12. Łuczaj, Ł.; ZovkoKončić, M.; Miličević, T.; Dolina, K.; Pandža, M. Wild vegetable mixes sold in the markets of Dalmatia (southern Croatia). J. Ethnobiol. Ethnomed. 2013, 9, 2. [CrossRef] [PubMed]

13. Ludvig, A.; Tahvanainen, V.; Dickson, A.; Evard, C.; Kurttila, M.; Cosovic, M.; Chapman, E.; Wilding, M.; Weiss, G. The practice of entrepreneurship in the non-wood forest products sector: Support for innovation on private forest land. For. Policy Econ. 2016, 66, 31-37. [CrossRef]

14. Seeland, K.; Staniszewski, P. Indicators for a European Cross-country State-of-the-Art Assessment of Non-timber Forest Products and Services. Small-Scale For. 2007, 6, 411-422. [CrossRef]

15. Weiss, G.; Ludvig, A.; Zivojinovic, I.; Asamer-Handler, M.; Huber, P. Non-timber innovations: How to innovate in side-activities of forestry Case study Styria, Austria. Austrian J. For. Sci. 2017, 134, 231-250. 
16. Ticktin, T. The ecological sustainability of non-timber forest product harvest. In Ecological Sustainability for Non-Timber Forest Products: Dynamics and Case Studies of Harvesting; Shackleton, C.M., Pandey, A.K., Ticktin, Tamara, Eds.; Routledge: London, UK; New York, NY, USA, 2015; pp. 31-52.

17. Shanley, P. Tapping the Green Market: Certification and Management of Non-Timber Forest Products; Earthscan: London, UK, 2002.

18. Duchelle, A.E.; Kainer, K.A.; Wadt, L.H.O. Is Certification Associated with Better Forest Management and Socioeconomic Benefits? A Comparative Analysis of Three Certification Schemes Applied to Brazil Nuts in Western Amazonia. Soc. Nat. Resour. 2014, 27, 121-139. [CrossRef]

19. FSC International Standard: FSC Principles and Criteria for Forest Stewardship; Forest Stewardship Council: Bonn, Germany, 2015.

20. The IFOAM Norms for Organic Production and Processing; IFOAM: Bonn, Germany, 2014.

21. Fairtrade Standard for Small Producer Organizations; Fairtrade International: Bonn, Germany, 2005.

22. FairWild Standard Version 2.0/Performance Indicators; FairWild Foundation: Weinfelden, Switzerland, 2010.

23. Renna, M.; Cocozza, C.; Gonnella, M.; Abdelrahman, H.; Santamaria, P. Elemental characterization of wild edible plants from countryside and urban areas. Food Chem. 2015, 177, 29-36. [CrossRef] [PubMed]

24. Işıloğlu, M.; Yılmaz, F.; Merdivan, M. Concentrations of trace elements in wild edible mushrooms. Food Chem. 2001, 73, 169-175. [CrossRef]

25. European Union Council Regulation (EC) No 834/2007 of 28 June 2007 on Organic Production and Labelling of Organic Products; Official Journal of the European Union: Brussels, Belgum, 2007.

26. European Union Commission Regulation (EC) No 889/2008 of 5 September 2008 Laying down Detailed Rules for the Implementation of Council Regulation (EC) No 834/2007 on Organic Production and Labelling of Organic Products with Regard to Organic Production, Labelling and Control; Official Journal of the European Union: Brussels, Belgum, 2008.

27. Willer, H.; Lernoud, J. The World of Organic Agriculture-Statistics and Emerging Trends 2017; Research Institute of Organic Agriculture (FiBL) and IFOAM-Organics International: Frick and Bonn: Bonn, Germany, 2017.

28. Eurostat Population and Population Change Statistics. Available online: http://ec.europa.eu/eurostat/ statistics-explained/index.php/Population_and_population_change_statistics\#EU-28_population_ continues_to_grow (accessed on 9 July 2018).

29. Christanell, A.; Vogl-Lukasser, B.; Vogl, C.R.; Guetler, M. The cultural significance of wild gathered plant species in Kartitsch (Eastern Tyrol, Austria) and the influence of socio- economic changes on local gathering practices. In Ethnobotany in Europe; Pardo de Santayana, M., Pieroni, A., Puri, R., Eds.; Berghahn Books: Oxford, UK, 2010; pp. 51-75.

30. Schunko, C.; Grasser, S.; Vogl, C.R. Intracultural variation of knowledge about wild plant uses in the Biosphere Reserve Grosses Walsertal (Austria). J. Ethnobiol. Ethnomed. 2012, 8, 23. [CrossRef] [PubMed]

31. Schunko, C.; Vogl, C. Organic farmers use of wild food plants and fungi in a hilly area in Styria (Austria). J. Ethnobiol. Ethnomed. 2010, 6, 17. [CrossRef] [PubMed]

32. Vogl, C.R.; Vogl-Lukasser, B.; Walkenhorst, M. Local knowledge held by farmers in Eastern Tyrol (Austria) about the use of plants to maintain and improve animal health and welfare. J. Ethnobiol. Ethnomed. 2016, 12, 40. [CrossRef] [PubMed]

33. Peintner, U.; Schwarz, S.; Mešić, A.; Moreau, P.-A.; Moreno, G.; Saviuc, P. Mycophilic or Mycophobic? Legislation and Guidelines on Wild Mushroom Commerce Reveal Different Consumption Behaviour in European Countries. PLoS ONE 2013, 8, e63926. [CrossRef] [PubMed]

34. Vacik, H.; Wolfslehner, B.; Huber, P.; Ruprecht, H. Analysis of Non Wood Forest Products and Forest Services in Sustainable Forest Management. Aust. J. For. Sci. 2014, 131, 147-170.

35. BMLFUW Grüner Bericht 2017-Bericht über die Situation der österreichischen Land- und Forstwirtschaft; Bundesministerium für Land- und Forstwirtschaft, Umwelt und Wasserwirtschaft: Wien, Austria, 2017.

36. Eurostat Land Cover and Land Use (LUCAS) Statistics. Available online: http:/ / ec.europa.eu/eurostat/ statistics-explained/index.php/Land_cover_and_land_use_(LUCAS)_statistics (accessed on 9 July 2018).

37. Eurostat Land Cover, Land Use and Landscape. Available online: http://ec.europa.eu/eurostat/statisticsexplained/index.php/Land_cover,_land_use_and_landscape (accessed on 9 July 2018).

38. Fischer, M.A.; Oswald, K.; Adler, W. Exkursionsflora für Österreich, Liechtenstein und Südtirol; 3. Auflage.; Land Oberösterreich, Biologiezentrum der Oberösterreichischen Landesmuseen: Linz, Austria, 2008.

39. Creswell, J.W. Research Design: Qualitative, Quantitative, and Mixed Methods Approaches; Sage Publications: Thousand Oaks, CA, USA, 2013. 
40. Bogner, A.; Littig, B.; Menz, W. Interviews Mit Experten: Eine Praxisorientierte Einführung; Springer: Wiesbaden, Germany, 2014.

41. Microsoft Excel 2010; Microsoft Corporation: Redmont, AB, Canada, 2010.

42. MPNS Medicinal Plant Names Services Kew. Available online: https://www.kew.org/science/data-andresources/tools-and-services/medicinal-plant-names-services (accessed on 9 July 2018).

43. European Commission Integrated Administration and Control System (IACS). Available online: https:/ / ec.europa. eu/agriculture/direct-support/iacs_en (accessed on 9 July 2018).

44. European Union Council Regulation (EC) No 1242/2008 of 8 Dec 2008 on Establishing a Community Typology for Agricultural Holdings; Official Journal of the European Union: Brussels, Belgum, 2008.

45. IBM SPSS Statistics 24; IBM: Armonk, NY, USA, 2016.

46. Atlas.ti 7; ATLAS.ti Scientific Software Development GmbH: Berlin, Germany, 2017.

47. Kluge, S. Empirisch begründete Typenbildung: Zur Konstruktion von Typen und Typologien in der Qualitativen Forschung; Leske+Budrich: Opladen, Germany, 1999.

48. Guest, G.; Bunce, A.; Johnson, L. How many interviews are enough? An experiment with data saturation and variability. Field Methods 2006, 18, 59-82. [CrossRef]

49. Grasser, S.; Schunko, C.; Vogl, C.R. Gathering "tea"-from necessity to connectedness with nature. Local knowledge about wild plant gathering in the Biosphere Reserve Grosses Walsertal (Austria). J. Ethnobiol. Ethnomed. 2012, 8, 31. [CrossRef] [PubMed]

50. Weltin, M.; Zasada, I.; Franke, C.; Piorr, A.; Raggi, M.; Viaggi, D. Analysing behavioural differences of farm households: An example of income diversification strategies based on European farm survey data. Land Use Policy 2017, 62, 172-184. [CrossRef]

51. Meraner, M.; Heijman, W.; Kuhlman, T.; Finger, R. Determinants of farm diversification in the Netherlands. Land Use Policy 2015, 42, 767-780. [CrossRef]

52. Statistik Austria Agrarstrukturerhebung 2010—Gesamtergebnisse; Verlag Austria Gmbh: Wien, Austria, 2013.

53. Reyes-García, V.; Menendez-Baceta, G.; Aceituno-Mata, L.; Acosta-Naranjo, R.; Calvet-Mir, L.; Domínguez, P.; Garnatje, T.; Gómez-Baggethun, E.; Molina-Bustamante, M.; Molina, M.; et al. From famine foods to delicatessen: Interpreting trends in the use of wild edible plants through cultural ecosystem services. Ecol. Econ. 2015, 120, 303-311. [CrossRef]

54. Menendez-Baceta, G.; Pardo-de-Santayana, M.; Aceituno-Mata, L.; Tardío, J.; Reyes-García, V. Trends in wild food plants uses in Gorbeialdea (Basque Country). Appetite 2017, 112, 9-16. [CrossRef] [PubMed]

55. Barthel, S.; Folke, C.; Colding, J. Social-ecological memory in urban gardens-Retaining the capacity for management of ecosystem services. Glob. Environ. Chang. 2010, 20, 255-265. [CrossRef]

56. De Cortes Sánchez-Mata, M.; Tardío, J. Mediterranean Wild Edible Plants: Ethnobotany and Food Composition Tables; Springer: New York, NY, USA, 2016.

57. Łuczaj, Ł.; Pieroni, A.; Tardío, J.; Pardo-de-Santayana, M.; Sõukand, R.; Svanberg, I.; Kalle, R. Wild food plant use in 21st century Europe, the disapperance of old traditions and the search for new cuisines involving wild edibles. Acta Societatis Botanicorum Poloniae 2012, 81. [CrossRef]

58. Kilchling, P.; Hansmann, R.; Seeland, K. Demand for non-timber forest products: Surveys of urban consumers and sellers in Switzerland. For. Policy Econ. 2009, 11, 294-300. [CrossRef]

59. De Román, M.; Boa, E. The marketing of Lactarius deliciosus in Northern Spain. Econ. Bot. 2006, 60, $284-290$. [CrossRef]

(C) 2018 by the authors. Licensee MDPI, Basel, Switzerland. This article is an open access article distributed under the terms and conditions of the Creative Commons Attribution (CC BY) license (http:/ / creativecommons.org/licenses/by/4.0/). 